\title{
IMPLEMENTASI SISTEM INFORMASI PENGOLAHAN DATA PASIEN PADA KLINIK PRATAMA INSAN HUSADA CIAMIS JAWA BARAT
}

\author{
Novita Indriyani ${ }^{1}$ \\ Program Studi Sistem Informasi Akuntansi \\ Universitas Bina Sarana Informatika \\ Email : novita.nvd@bsi.ac.id
}

\author{
Indarti $^{2}$ \\ Program Studi Sistem \\ Universitas Bina Sarana Informatika \\ Email : indarti.ini@bsi.ac.id
}

\begin{abstract}
Abstrak-- Perkembangan teknologi pada saat ini telah banyak mengalami kemajuan yang sangat pesat baik dalam software maupun hardware. Dengan adanya perkembangan merupakan kesempatan terbaik untuk Klinik Pratama Insan Husada memanfaatkannya dengan membuat sistem informasi yang menunjang kinerja Klinik dalam memberikan pelayanan yang lebih baik. Klinik pratama Insan Husada dalam mengelola administrasi khususnya untuk pasien rawat jalan masih menggunakan administrasi manual, baik dalam pendaftaran pasien, penyimpanan data-data klinik, pencatatan transaksi, sampai pembuatan laporan. Saat ini, sistem manual yang masih diterapkan oleh Klinik Pratama Insan Husada sangat memungkinkan terjadinya kesalahan dalam
\end{abstract}

\section{PENDAHULUAN}

Sistem informasi pengolahan data pasien disebuah klinik pratama insan husada ciamis jawa barat masih menggunakan metode konvensional dengan media kertas sebagai bahan penyimpanan, pencarian yang membuthkan waktu yang sangat lama. Klinik Pratama Insan Husada adalah sebuah lembaga yang bergerak di bidang kesehatan yang mempunyai tujuan untuk memberikan pelayanan kesehatan kepada masyarakat yang aman, berkualitas dan memuaskan.

Menurut (Usman, 2002, 70) Implementasi adalah bermuara pada aktivitas, aksi, tindakan, atau adanya mekanisme suatu sistem. Implementasi bukan sekedar aktivitas, tetapi suatu kegiatan yang terencana dan untuk mencapai tujuan kegiatan.

Menurut (Azhar Susanto, 2013) Sistem informasi adalah kumpulan dari sub-sub sistem baik phisik maupun non phisik yang saling berhubungan satu sama lain dan bekerja sama secara harmonis untuk mencapai satu tujuan yaitu mengolah data menjadi informasi yang berguna. pencatatan, kurang akuratnya informasi yang dibuat, keterlambatan dalam pencarian data-data yang diperlukan bahkan terjadinya kehilangan data. Sistem terkomputerisasi merupakan solusi yang terbaik untuk memecahkan permasalahanpermasalahan yang ada pada Klinik Pratama Insan Husada. Maka dari itu dengan sistem yang terkomputerisasi lebih baik dari sistem yang manual, sistem ini pada intinya berfungsi untuk membantu pihak klinik melakukan pengelolaan data pada klinik dan membantu pasien untuk mendapatkan informasi pelayanan.

Kata Kunci : Implementasi Sistem Informasi, Pengolahan Data Pasien

Menurut (Sutanta, 2004) data adalah bahan keterangan tentang kejadian-kejadian nyata atau fakta-fakta yang dirumuskan dalam sekelompok lambang tertentu yang tidak diacak yang menunjukkan jumlah, tindakan, atau hal. Data merupakan nilai keadaan atau sifat yang berdiri sendiri-sendiri lepas dari konteks apapun (Al Fatah, 2007).

Menurut (Rosa A. S, 2016) "Model SDLC air terjun (waterfall) sering juga disebut model sekuensial linier (sequential linear) atau alur hidup klasik (classic life cycle)".

Menurut (Rosa A. S, 2016) ERD adalah bentuk paling awal dalam melakukan perancangan basis data relasional.

Menurut (Hasugian, Humisar, dan Ahmad, Nur, 2012) "LRS adalah sebuah model sistem yang digambarkan dengan seuah diagram-ER akan mengikuti pola atau aturan pemodelan tertentu dalam kaitannya dengan konvensi ke $L R S$ ".

Menurut (Putri dan Wulandari, 2016) mengatakan bahwa,"UML (Unified Modelling Languange) adalah salah satu standar bahasa yang banyak 
digunakan di dunia industri untuk mendefinisikan requirement, membuat analisis dan desain, serta menggambarkan arsitektur dalam pemrograman berorientasi objek".

Menurut (Nuryamin dan Hermawan, 2017) mengemukakan bahwa, "Netbeans merupakan salah satu IDE yang dikembangkan dengan bahasa pemrograman java. Netbeans mempunyai lingkup pemrograman java terintergrasi dalam suatu perangkat lunak yang didalamnya menyediakan pembangunan pemrograman GUI, text editor,compiler, dan interpreter.

Menurut (Nuryamin dan Hermawan, 2017) mengemukakan bahwa, "Netbeans merupakan salah satu IDE yang dikembangkan dengan bahasa pemrograman java. Netbeans mempunyai lingkup pemrograman java terintergrasi dalam suatu perangkat lunak yang didalamnya menyediakan pembangunan pemrograman GUI, text editor,compiler, dan interpreter.

\section{METODOLOGI PENELITIAN}

Waterfall model yang digunakan didalam penelitian ini. Yang menggambarkan adanya tingkatan di dalam merancang sebuah rancang bangun sistem informasi pelayanan kesehatan pada klinik umum. Metode waterfall yang digunakan pada penelitian ini meliputi : (1) Perencanaan, (2) Analisis, (3) Perancangan, (4) Implementasi, dan (5) Pemeliharaan.

\section{HASIL DAN PEMBAHASAN}

1. Analisa Kebutuhan

A.1. Admin melakukan login.

A.2. Admin membuka Menu Utama.

A.3. Admin Membuka Pendaftaran Pasien.

A.3.1. Admin menambah Data Pasien.

A.3.2. Admin menambah Pendaftaran Pasien

A.4. Admin membuka Pembayaran.

A.4.1. Admin menginput pembayaran pasien.

A.5. Admin Membuka Jurnal Umum

A.5.1. Admin mengimput Jurnal Umum.

A.6. Admin Membuka Master Data

A.6.1. Admin mengimput Data Pasien.

A.6.2. Admin mengimput Data Dokter.

A.6.3. Admin mengimput Data User.

A.6.4. Admin mengimput Data Obat.

A.6.5. Admin mengimput Data Tindakan.

A.6.6. Admin mengimput Data Perkiraan.

A.7. Admin Membuka Laporan.

A.7.1. Admin mencetak Laporan Data Pasien.

A.7.2. Admin mencetak Laporan Data User.

A.7.3. Admin mencetak laporan Data Obat.

A.7.4. Admin mencetak Laporan Pendapatan.
A.8. Admin Logout.

B.1. Perawat melakukan Login.

B.2. Perawat membuka Menu Utama.

B.3. Perawat membuka Data Rekam Medis.

B.3.1. Perawat mengimput Data Rekam Medis.

B.4. Perawat membuka Resep Obat

B.4.1. Perawat mengimput Resep Obat.

B.5. Perawat melakukan logout.

2. Perancangan Menggunakan UML

a. Use Case Diagram Admin

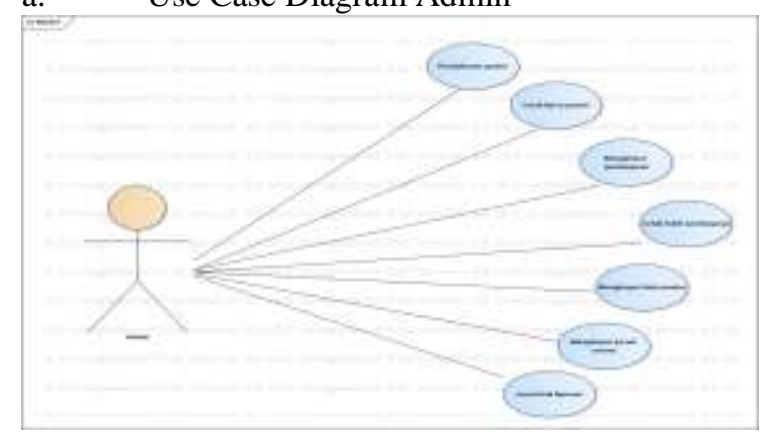

Gambar 1.

Use Case Diagram Admin

b. Use Case Menu Perawat

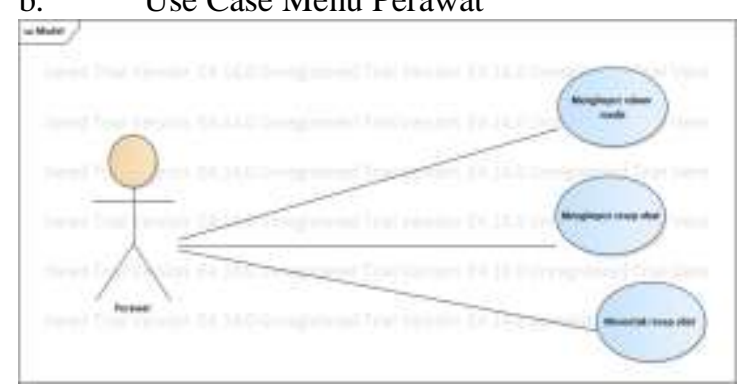

Gambar 2.

Use Case Perawat

c. Activity Diagram Usulan Pendaftran

Pasien 


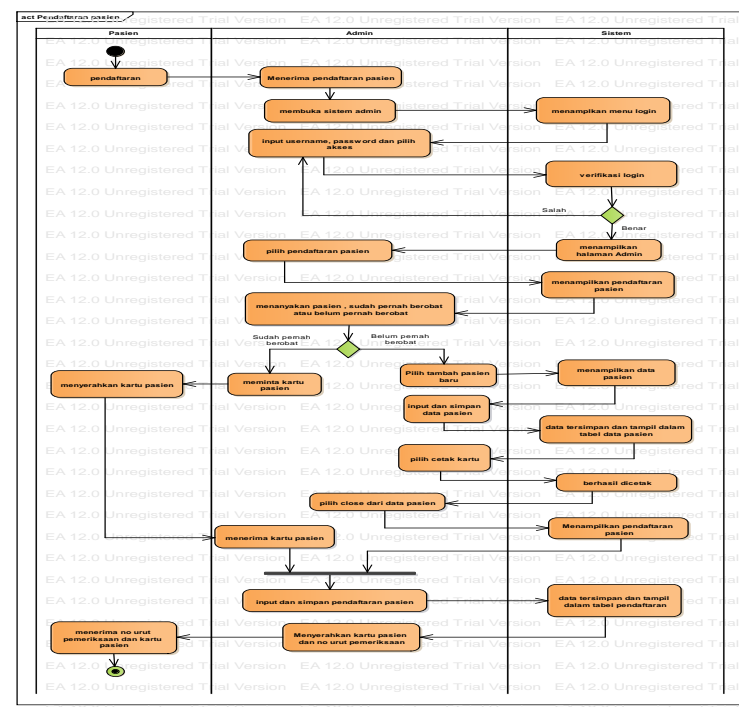

Gambar 3.

Activity Diagram Usulan Pendaftaran Pasien

d. Activity Diagram Usulan Pemeriksaan

Pasien

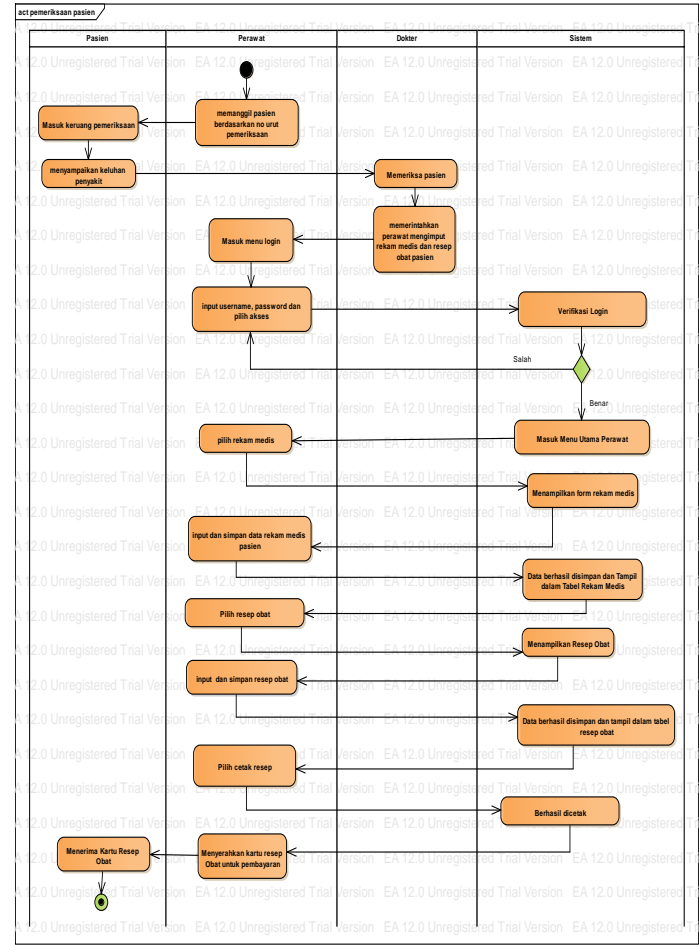

Gambar 4.

Activity Diagram Usulan Pemeriksaan Pasien

e. Activity Diagram Usulan Pembayaran

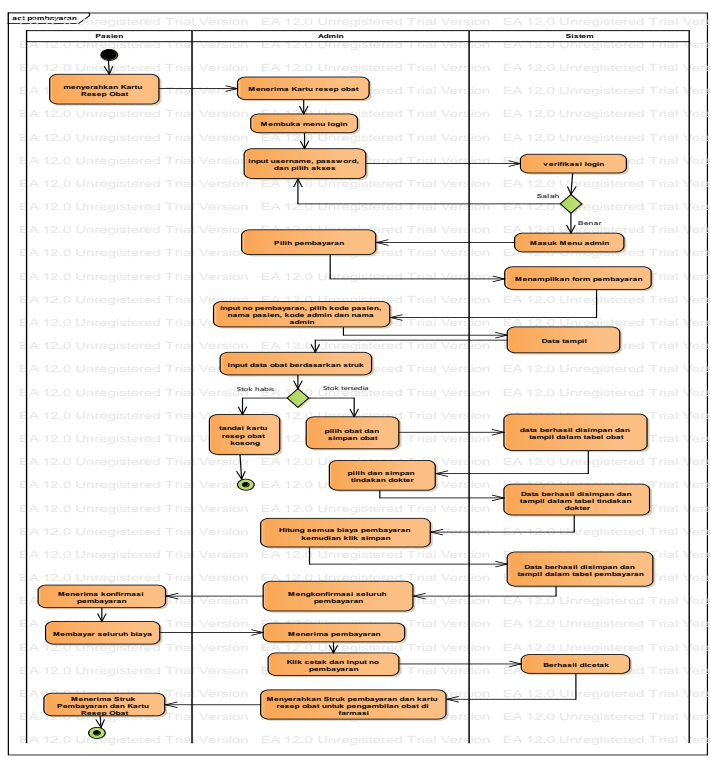

Gambar 5.

Activity Diagram Usulan Pembayaran

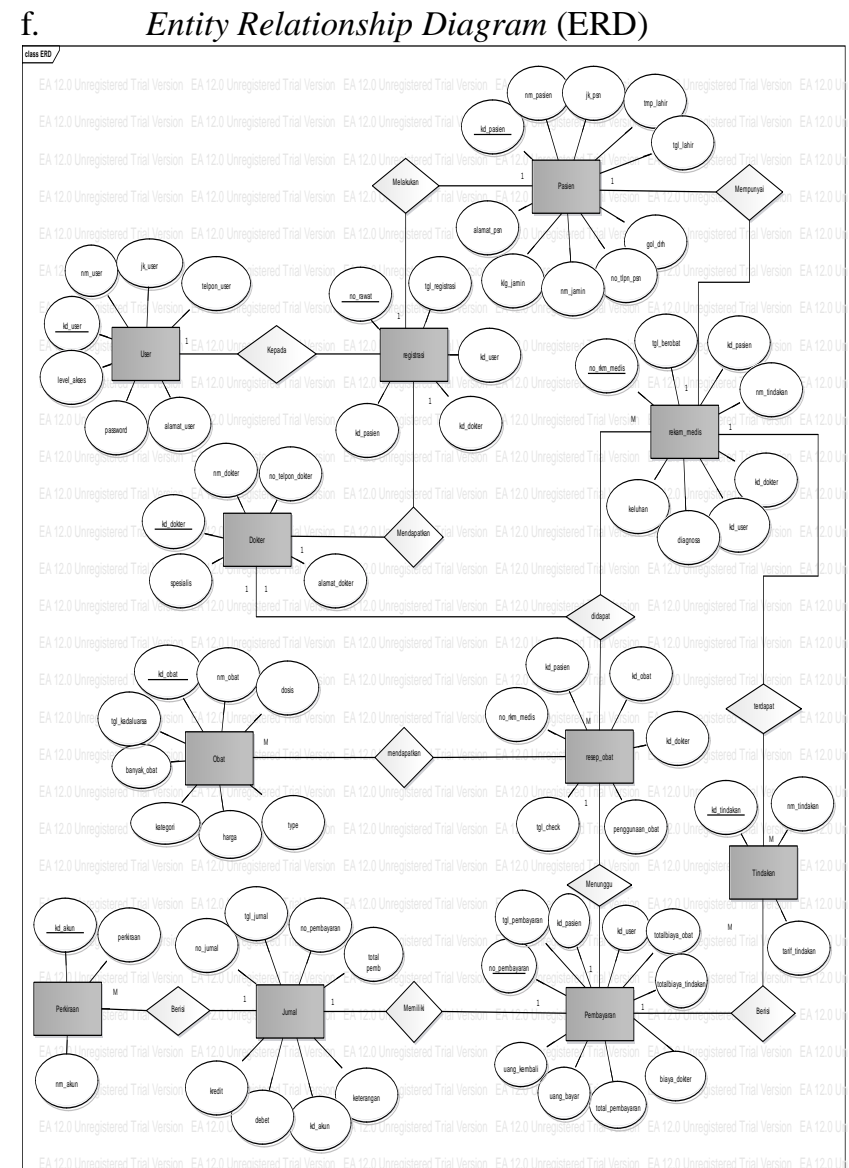

Gambar 6.

Entity Relationship Diagram (ERD) 


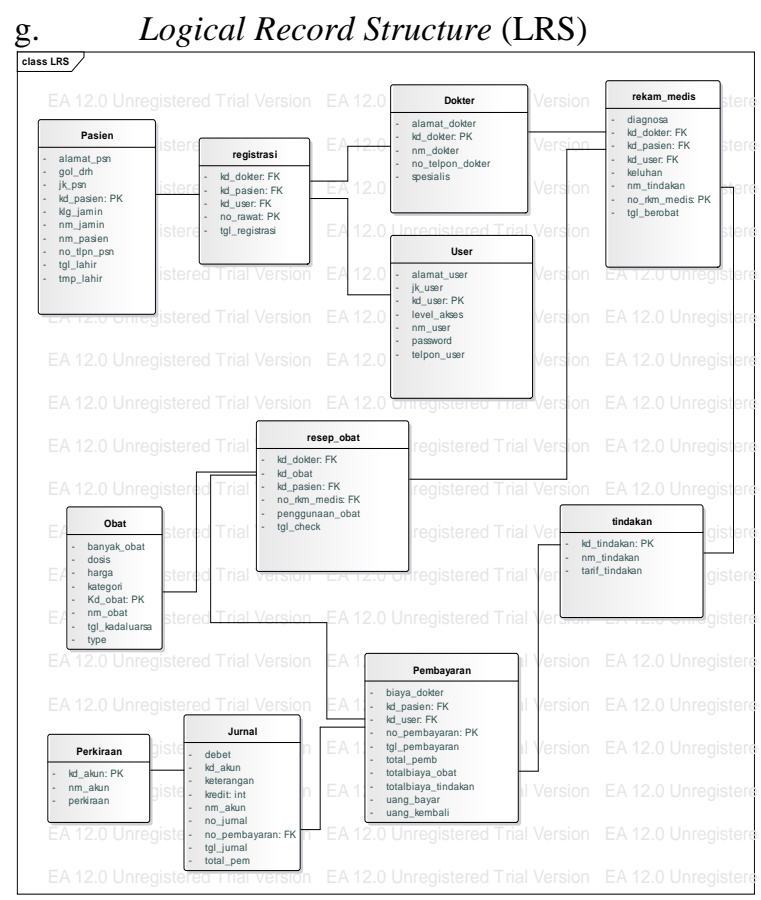

Gambar 7.

Logical Record Structure (LRS)

h. Sequence Diagram Pembayaran

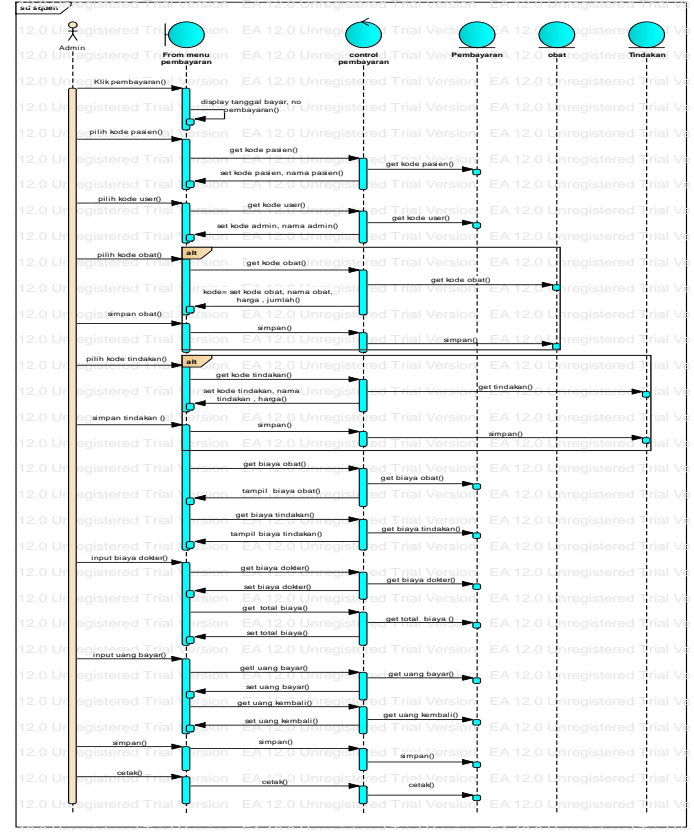

Gambar 8.

Squence Diagram Pembayaran

i. Deployment Diagram

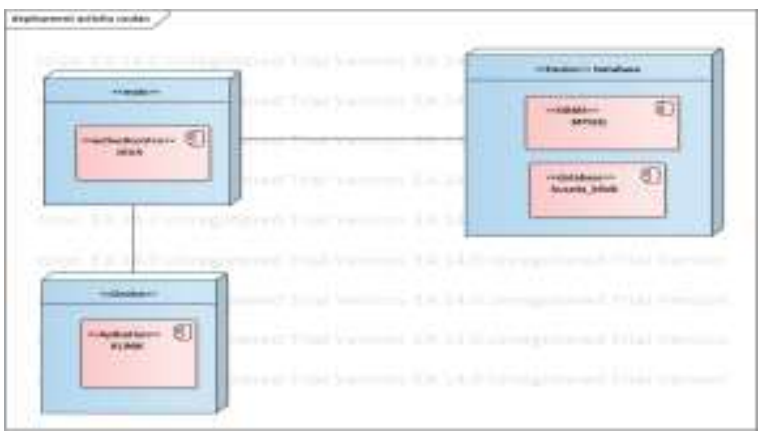

Gambar 9.

Deployment Diagram

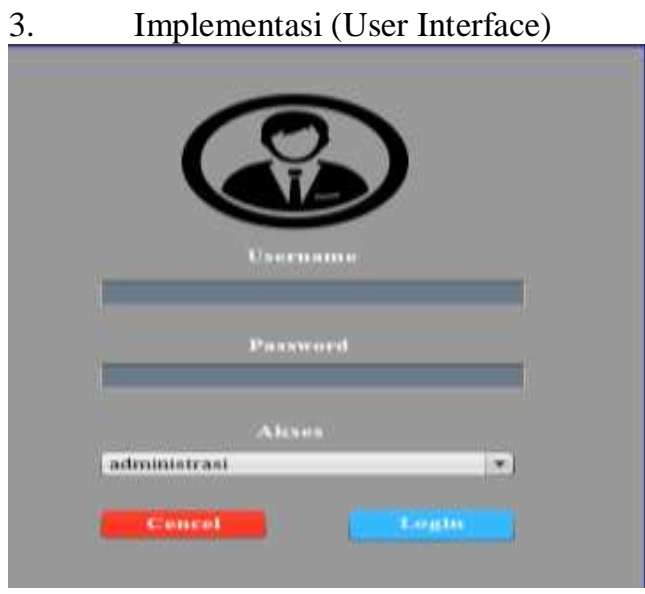

Gambar 10.

User Interface Login

a. User Interface Menu Utama Admin

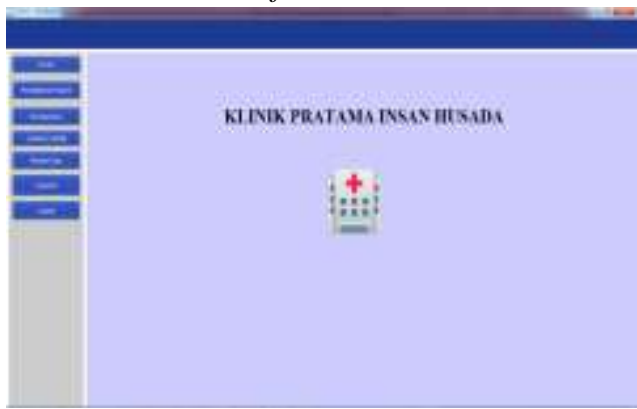

Gambar 11.

User Interface Menu Utama Admin

b. User Interface Pendaftaran Pasien

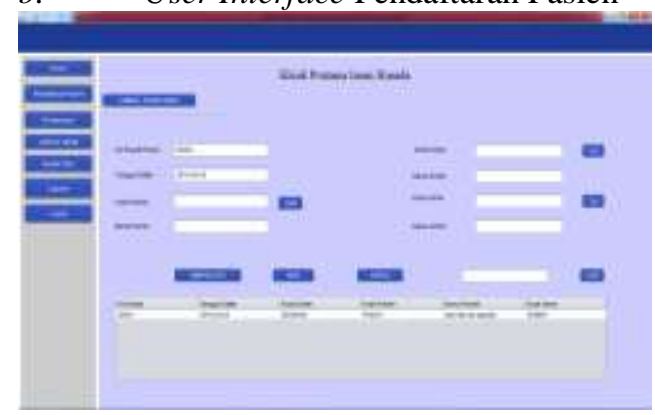

Gambar 12.

User Interface Pendaftaran Pasien 


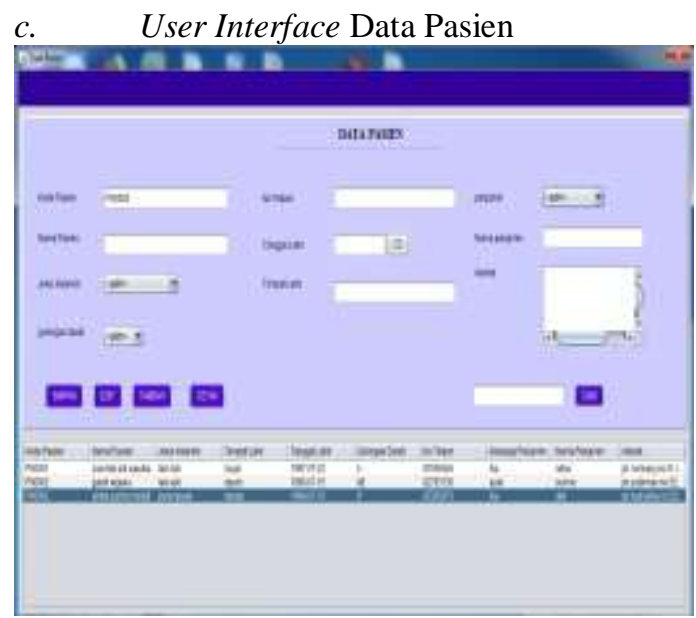

\section{Gambar 13.}

User Interface Data Pasien

d. User Interface Data Dokter

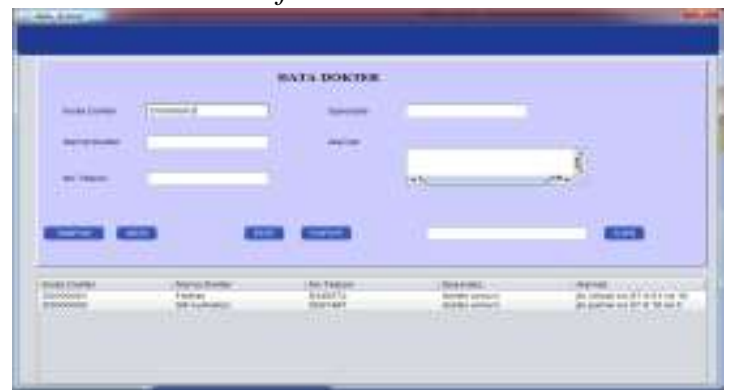

Gambar 14.

User Interface Data Dokter

e. $\quad$ User Interface Data User

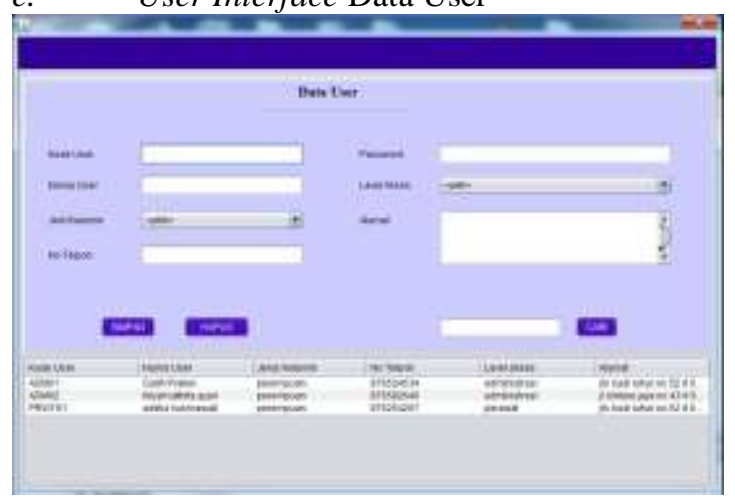

Gambar 15.

User Interface Data User

f. $\quad$ User Interface Data Obat

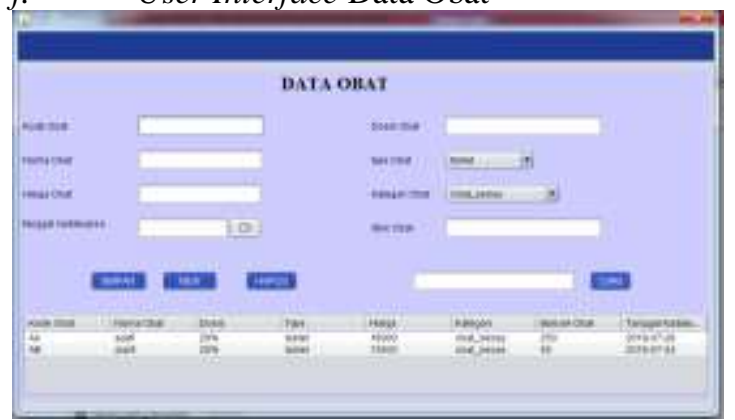

Gambar 16.

User Interface Data Obat

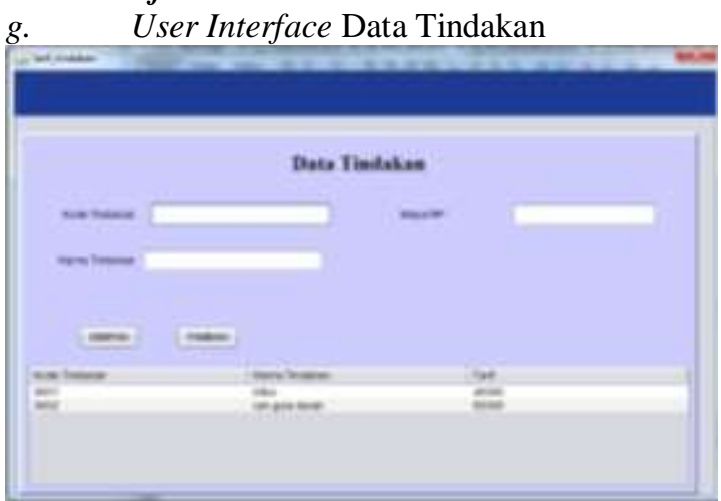

Gambar 17.

User Interface Data Tindakan

$h$. User Interface Data Perkiraan

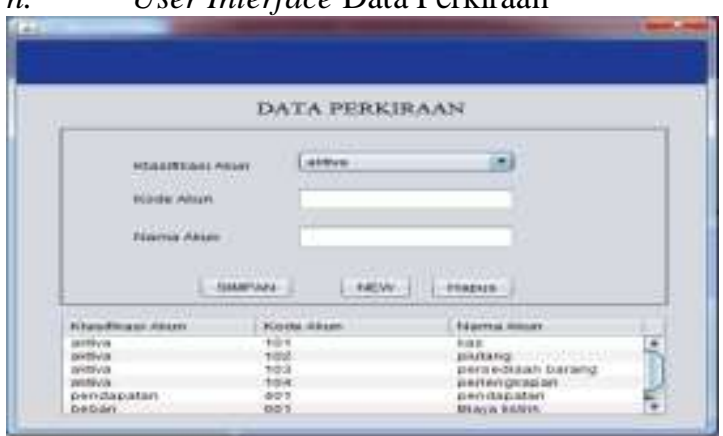

Gambar 18.

User Interface Data Tindakan

$i$ User Interface Data Pembayaran

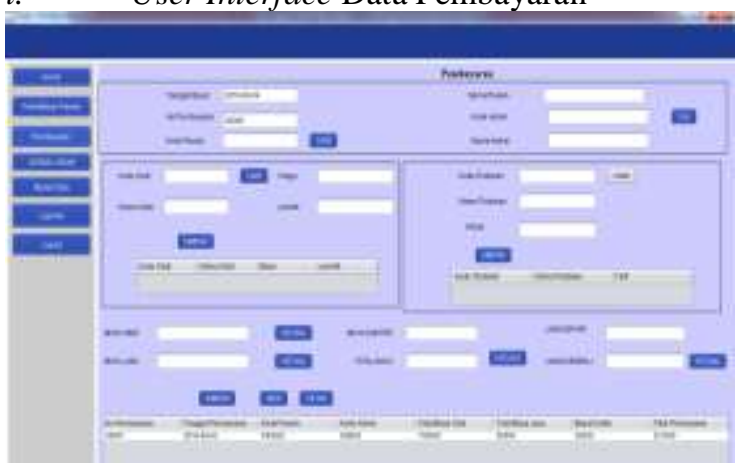

Gambar 19.

User Interface Data Pembayaran

j. $\quad$ User Interface Data Jurnal Umum

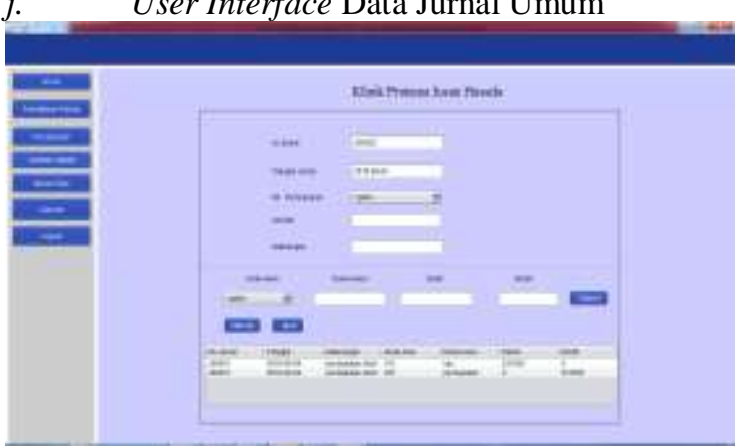


Gambar 20.

User Interface Data Jurnal Umum

k. User Interface Menu Utama Perawat

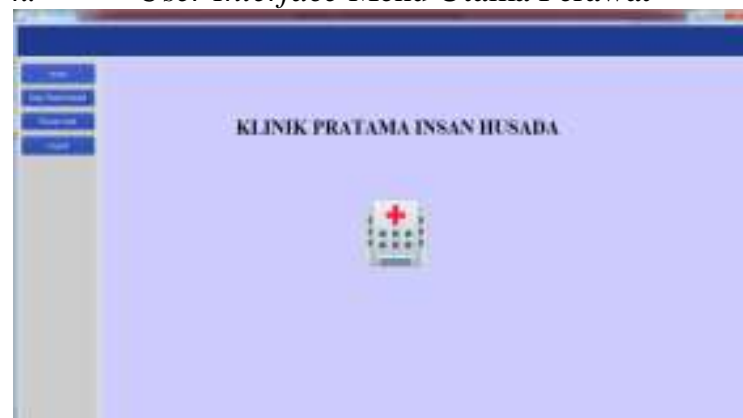

Gambar 21.

User Interface Menu Utama Perawat

l. User Interface Data Rekam Medis Pasien

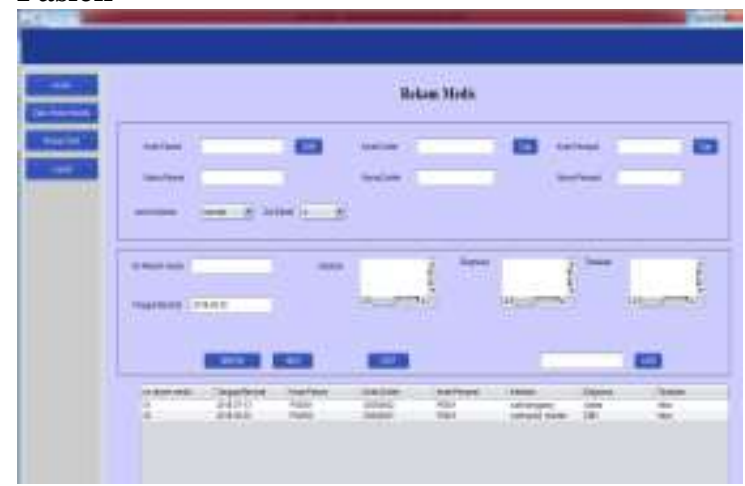

Gambar 22.

User Interface Data Rekam Medis

m. User Interface Data Resep Obat

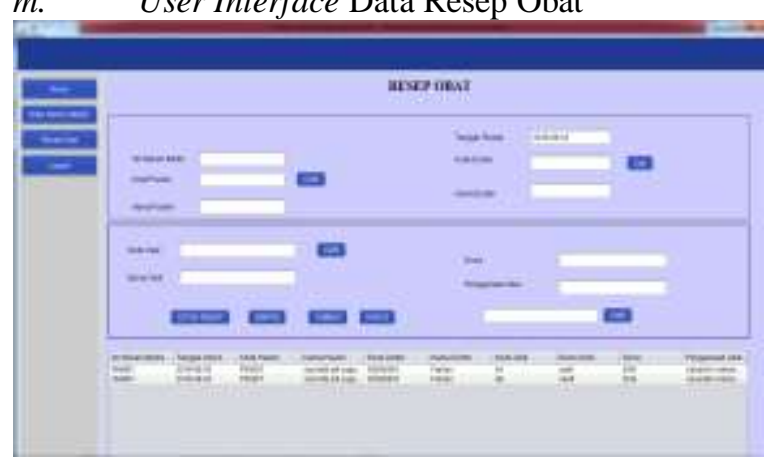

Gambar 23.

User Interface Data Resep Obat

$n$. User Interface Cetak resep obat Pasien

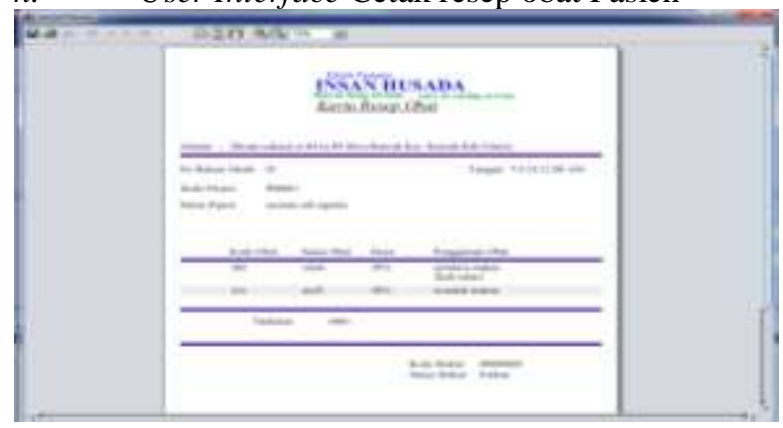

Gambar 24.

User Interface Cetak Resep Obat Pasien

o. User Interface Cetak Kartu Pasien

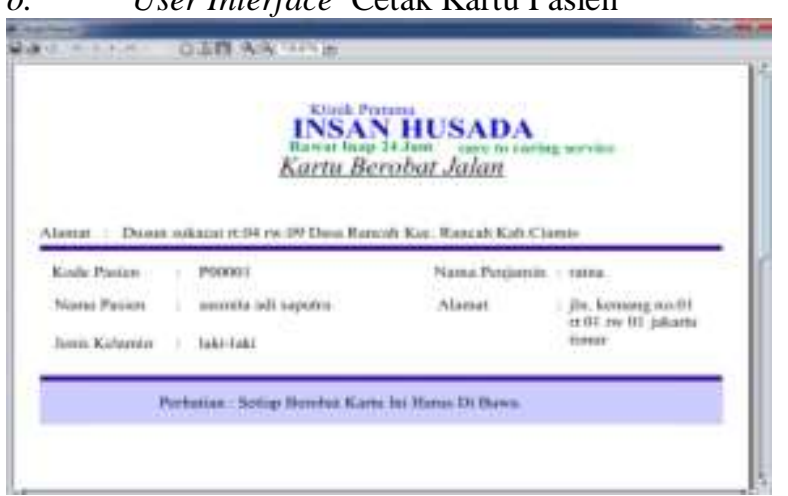

Gambar 25.

User Interface Cetak Kartu Pasien

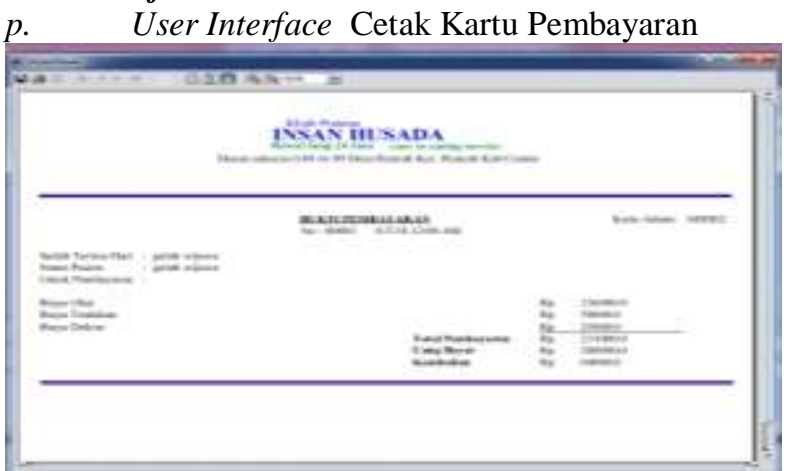

Gambar 26.

User Interface Cetak Kartu Pembayaran

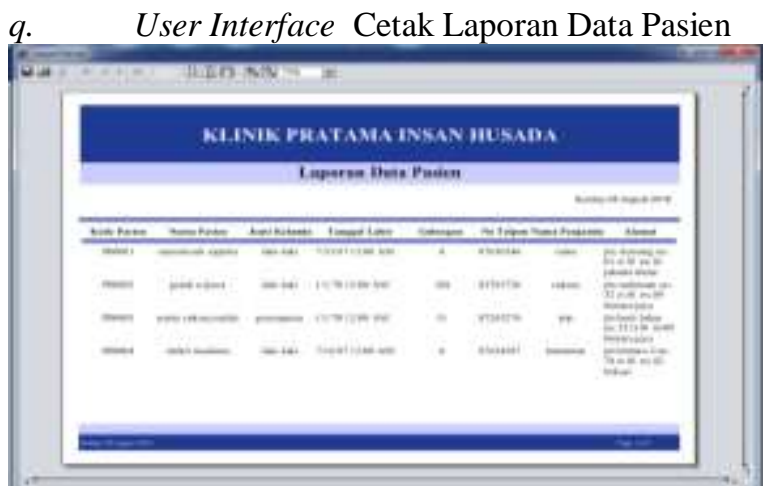

Gambar 27.

User Interface Cetak Laporan Data Pasien

$r$ User Interface Laporan Data Obat 


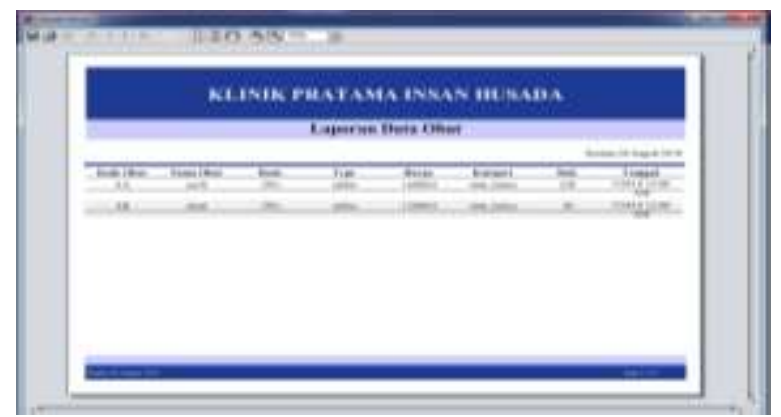

Gambar 28.

User Interface Cetak Laporan Data Obat

s. $\quad$ User Interface Laporan Data User

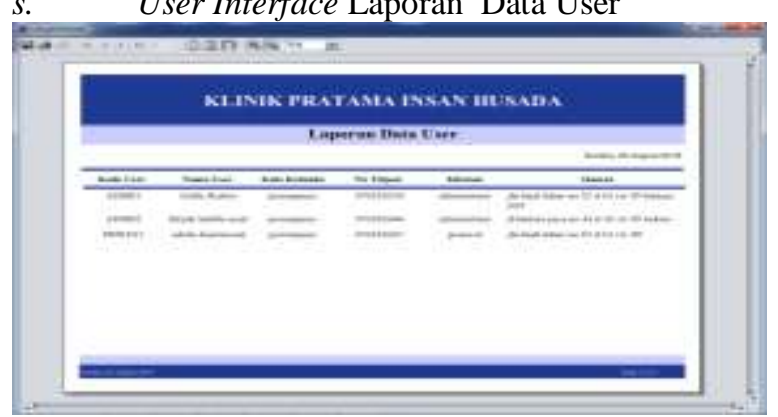

Gambar 29.

User Interface Laporan Data User

t. $\quad$ User Interface Laporan Pendapatan Klinik

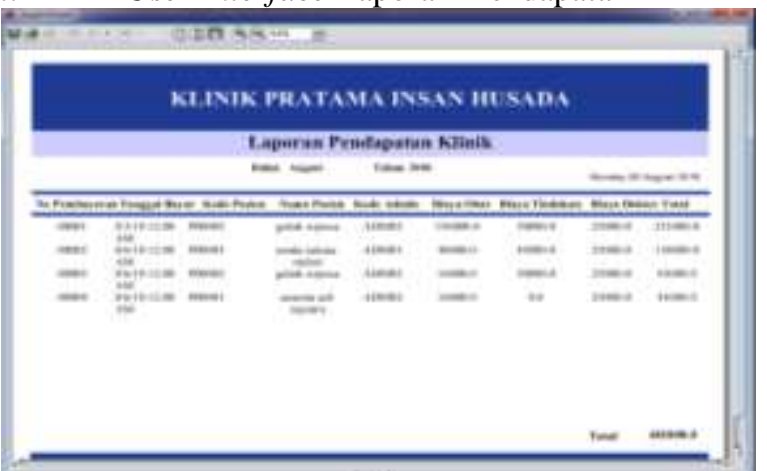

Gambar 30.

User Interface Laporan Pendapatan Klinik KESIMPULAN

1. Klinik Pratama Insan Husada adalah sebuah lembaga yang bergerak di bidang kesehatan yang mempunyai tujuan untuk memberikan pelayanan kesehatan kepada masyarakat yang aman, berkualitas, dan memuaskan.

2. Peralihan sistem, dari sistem konvensional ke sistem terkomputerisasi Klinik Pratama Insan Husada dapat meningkatkan kinerja klinik.

3. Pengolahan data dengan sistem informasi secara terkomputerisasi pada Klinik Pratama Insan Husada akan lebih memudahkan pegawainya dalam melaksanakan tugas-tugasnya terutama dalam pengelolaan data pasien, pendaftaran pasien, penyimpanan rekam medis, input resep obat, pembayaran, dan laporan.

\section{DAFTAR PUSTAKA}

Akhiyar, D. (2017). SISTEM PAKAR UNTUK MENDIAGNOSA PENYAKIT THT ( TELINGA HIDUNG TENGGOROKAN ) MENGGUNAKAN METODE FORWARD CHAINING DENGAN BAHASA PEMROGRAMAN PHP DAN MYSQL di RS M . Ibnu Sina Padang. Jurnal Teknologi, 7(2), 248-258. https://doi.org/2541-1535

Baridwan, Z. (2017). Sistem Informasi Akuntansi (Edisi Kedu). Yogyakarta: BPFE-YOGYAKARTA. Dalis, S. (2017). Rancang Bangun Sistem Informasi Lembaga Penelitian Dan Pengabdian Masyarakat Berbasis Web. Jurnal Paradigma, 19(1), 1-8.

Harjunawati, S. (2017). Sistem Informasi Akuntansi Penjualan Berbasis Waterfall Model Untuk Perusahaan Dagang. Indonesian Journal on Computer and Information Technology, 2(2), 131138.

Herliana, A. (2014). Analisa Dan Perancangan Sistem Informasi Administrasi Data Pribadi Dan Nilai Mahasiswa Di Perguruan Tinggi (Studi Kasus Universitas Kebangsaan Bandung). Jurnal Informatika, I(2), 82-92.

Krismiaji. (2015). Sistem Informasi Akuntansi (Edisi Keem). Yogyakarta: Sekolah Tinggi Ilmu Manajemen YKPN.

Lipursari, A. (2013). Peran Sistem Informasi Manajemen (Sim) Dalam Pengambilan Keputusan. Jurnal Stie Semarang, 5(1), 26-37. https://doi.org/2252-7826

Mulyadi. (2016). Sistem Akuntansi (Edisi Empa). Salemba Empat.

Nuryamin, Y., \& Hermawan. (2017). Perancangan Sistem Informasi Penjualan Voucher Telekomunikasi PT . Telefast Indonesia dengan Gamu 1. 30 Menggunakan Metode Waterfall. Simposiun Nasional Ilmu Pengetahuan Dan Teknologi, 1(1), 218-224.

Putri, M. E., \& Wulandari, D. A. N. (2016). Sistem Informasi Monitoring Siswa Berbasis Web Dan SMS Gateway Pada SMK Negeri 37 Jakarta. Jurnal Teknik Komputer AMIK BSI, II(2), 49-55. Retrieved from http://ejournal.bsi.ac.id/ejurnal/index.php/ijse/articl e/download/2813/1837

Sudaryono. (2016). Metode Penelitian Pendidikan (Pertama). Jakarta: PrenadaMedia.

Tohari, H. (2014). Analisis Serta Perancangan Sistem Informasi Melalui Pendekatan UML. (S. Wibowo, Ed.) (Ed. 1). Yogyakarta: C.V ANDI OFFSET.

Utami, A. S. F., Hidayat, M. K., \& Setiawan, T. (2016). Sistem Informasi Pembelajaran Online Pada SMK Dharma Paramitha Cakung Jakarta Timur. Simposium Nasional Ilmu Pengetahuan Dan 
Teknologi, 1(1), 117-121.

Yusuf, A. M. (2014). Metode Penelitian Kuantitatif, Kualitatif \& Penelitian Gabungan (Pertama). Jakarta: Kencana.

\section{PROFIL}

Novita Indriyani, sukabumi 02 nov 1982 lulus Strata 1 di STMIK Nusa Mandiri Jakarta tahun 2007 prodi Sistem Informasi dan Strata 2 di pascasarjana STMIK Nusa Mandiri Jakarta pada tahun 2011. Aktif dalam pertemuan ilmiah dan seminar kepustakaan.
Indarti. Jakarta 10 September 1983. Lulus tahun 2008 di STMIK Swadharma Jakarta Jurusan Sistem Informasi. Lulus tahun 2011 di Pascasarjana STMIK Nusa Mandiri Jakarta Program) Program Studi Magister Ilmu Komputer. Aktif mengikuti seminar dan menulis paper di beberapa jurnal diantara Cakrawala, Pilar, Techno, Widya Cipta, Swabumi, Teknik Informatika, Sistem Informasi dan pernah mengikuti Seminar Nasional maupun Internasional. 